\section{A) Check for updates}

Cite this: Dalton Trans., 2019, 48 4248

Received 25th December 2018 Accepted 26th February 2019

DOI: $10.1039 / c 8 d t 05107 k$

rsc.li/dalton

\title{
Calcium formamidinate derivatives by hydride insertion of carbodiimides $\uparrow$
}

\author{
Joshua Dyall, Michael S. Hill, (D) * Mary F. Mahon, Luke Teh and Andrew S. S. Wilson \\ The carbodiimides, $\mathrm{Ar} / \mathrm{RN}=\mathrm{C}=\mathrm{NAr} / \mathrm{R},(\mathrm{Ar}=2,6$-di-isopropylphenyl (Dipp), 4-methylphenyl; $\mathrm{R}=$ tert- \\ butyl, cyclohexyl, iso-propyl), react with the polar $\mathrm{Ca}-\mathrm{H}$ bonds of the dimeric $\beta$-diketiminato calcium \\ hydride, $[(\mathrm{BDI}) \mathrm{CaH}]_{2}\left(\mathrm{BDI}=\mathrm{HC}\left\{(\mathrm{Me}) \mathrm{CN}-2,6-\mathrm{i}-\mathrm{Pr}_{2} \mathrm{C}_{6} \mathrm{H}_{3}\right\}_{2}\right)$, to provide a series of heteroleptic calcium for- \\ mamidinate derivatives. While reactions with carbodiimides bearing more sterically demanding substitu- \\ ents (Dipp, $t$-Bu, Cy) are straightforward, and provide four-coordinate compounds, less bulky iso-propyl \\ or 4-methylphenyl substitution results in the sequestration of a further equivalent of the carbodiimide and \\ the isolation of a heteroleptic hydride-bridged dinuclear species. This latter observation is suggested to \\ be a reflection of the robust dimeric constitution of the calcium hydride reagent and the reduced steric \\ demands of the di-para-tolyl carbodiimide reagent.
}

\section{Introduction}

Amidinate anions are among the most widely applied ligands in contemporary coordination and organometallic chemistry. ${ }^{1,2}$ Organic amidines are readily available by a variety of routes and are easily metallated by organometallic or amide bases derived from more electropositive elements. These species may, in turn, be applied in onward metathesis reactions with metal salts to provide a panoply of derivatives that encompasses the entirety of the periodic table. A further reliable route to $C$-alkyl amidinates involves the insertion of a carbodiimide, $\mathrm{RN}=\mathrm{C}=\mathrm{NR}(\mathrm{R}=$ alkyl or aryl), into the $\mathrm{M}-\mathrm{C}$ bond of a polar organometallic derivative (Scheme 1(a)). In cases where the parent formamidinate species are required, analogous access necessitates the availability of a suitably reactive, molecular metal hydride. Documented examples of this latter process include rare earth metal $\left(\mathrm{Y}^{3-5} \mathrm{La}^{6}\right.$ and $\left.\mathrm{Lu}^{7}\right)$, transition metal $\left(\mathrm{Fe},{ }^{8} \mathrm{Zr}^{9}{ }^{9} \mathrm{Nb}, \mathrm{Ta}^{10}\right.$ and $\left.\mathrm{Re}^{11}\right)$, p-block $\left(\mathrm{B},{ }^{12-15}\right.$ $\mathrm{Al},{ }^{16,17} \mathrm{Zn},{ }^{18-20} \mathrm{Ga}^{16}$ and $\left.\mathrm{Sn}^{21}\right)$ and s-block metal $\left(\mathrm{Li}^{22}\right.$ and $\mathrm{Mg}^{23,24}$ ) hydrides (Scheme 1(b)).

A variety of calcium amidinate species have been synthesised either by salt metathesis of a pre-formed anion with $\mathrm{CaI}_{2}$, by deprotonation of an amidine by $\left[\mathrm{Ca}\left\{\mathrm{N}\left(\mathrm{SiMe}_{3}\right)_{2}\right\}_{2}\right]_{2}$ or by carbodiimide insertion into the polar $\mathrm{Ca}-\mathrm{C}$ bonds of a terminal acetylide..$^{25-34}$ Of most relevance to the current work,

Department of Chemistry, University of Bath, Claverton Down, Bath, BA2 7AY, UK. E-mail:msh27@bath.ac.uk

$\dagger$ Electronic supplementary information (ESI) available: NMR spectra of compounds 3-7 and details of the crystallographic analysis of compounds 3, 4, 6 and 7. CCDC 1886241-1886244 for 3, 4, 6 and 7, respectively. For ESI and crystallographic data in CIF or other electronic format see DOI: 10.1039/c8dt05107k four homoleptic calcium formamidinate derivatives, $[\mathrm{Ca}\{(\mathrm{Ar} /$ $\left.\mathrm{RN})_{2} \mathrm{CH}\right\}_{2}$ (THF)] ( $\mathrm{Ar}=2$,6-di-isopropylphenyl (Dipp), $o$-methylphenyl, 2,6-dimethylphenyl; $\mathrm{R}=i$-Pr) have previously been reported. These latter compounds, however, were synthesised by a redox transmetallation process between the neutral amidine and elemental calcium, either in the presence of $\mathrm{Hg}$ $\left(\mathrm{C}_{6} \mathrm{~F}_{5}\right)_{2}$ or in liquid ammonia. ${ }^{35-37}$ Insertion reactions of carbodiimides with calcium hydride bonds are yet to be reported, a lacuna which may be traced to the relative dearth and only recent provenance of appropriately stable and soluble molecular calcium hydrides. ${ }^{32,38-48}$

A seminal report in s-block chemistry was provided by Harder's molecular $\beta$-diketiminato calcium hydride complex, $[(\mathrm{BDI}) \mathrm{CaH}(\mathrm{THF})]_{2} \quad\left(\mathrm{BDI}=\mathrm{HC}\left\{(\mathrm{Me}) \mathrm{CN}-2,6-i-\mathrm{Pr}_{2} \mathrm{C}_{6} \mathrm{H}_{3}\right\}_{2} ; \mathbf{1}\right) .{ }^{40}$ Although compound $\mathbf{1}$ and related species have been shown to react directly with the polar multiple bonds of small molecules containing $\mathrm{C}=\mathrm{O}, \mathrm{C} \equiv \mathrm{O}, \mathrm{C}=\mathrm{N}$ and $\mathrm{C} \equiv \mathrm{N}$ functionalities to provide the corresponding alkoxide and amide derivatives, ${ }^{41,49-53}$ its reactivity with carbodiimides appears to have escaped attention. This observation is particularly surprising given the ability of sterically demanding $C$-alkyl amidinate ligands to impart sufficient kinetic stability in their own right to stabilise hydrido derivatives of the heavier alkaline earth elements. ${ }^{32,54}$ We have recently reported that a non-THF solvated analogue of compound 1, compound 2 (see Scheme 2), reacts readily with the $\mathrm{C}=\mathrm{C}$ bonds of terminal $n$-alkenes to provide calcium alkyl species which display sufficient nucleophilicity to allow the direct alkylation of benzene and the heterolysis of dihydrogen under very mild conditions. ${ }^{55,56}$ In this contribution, we continue to assay the chemistry of compound 2 and report the outcome of its reactions with a representative palette of $N, N$-dialkyl- and $N, N$-diarylcarbodiimides. 


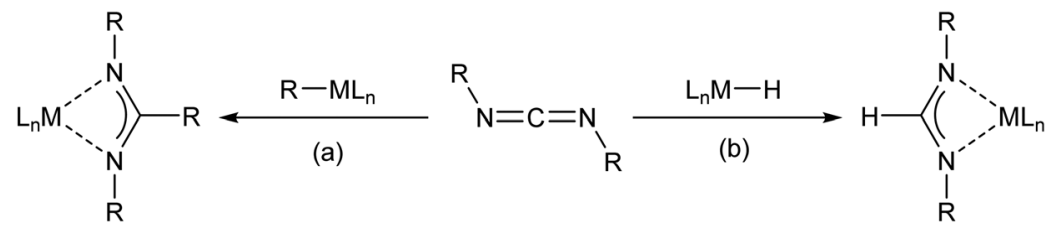

Scheme 1 Carbodiimide insertion into (a) the $\mathrm{M}-\mathrm{C}$ bond of a metal alkyl or aryl (b) the $\mathrm{M}-\mathrm{H}$ bond of a metal hydride to provide the respective alkyl- and formamidinate derivatives.

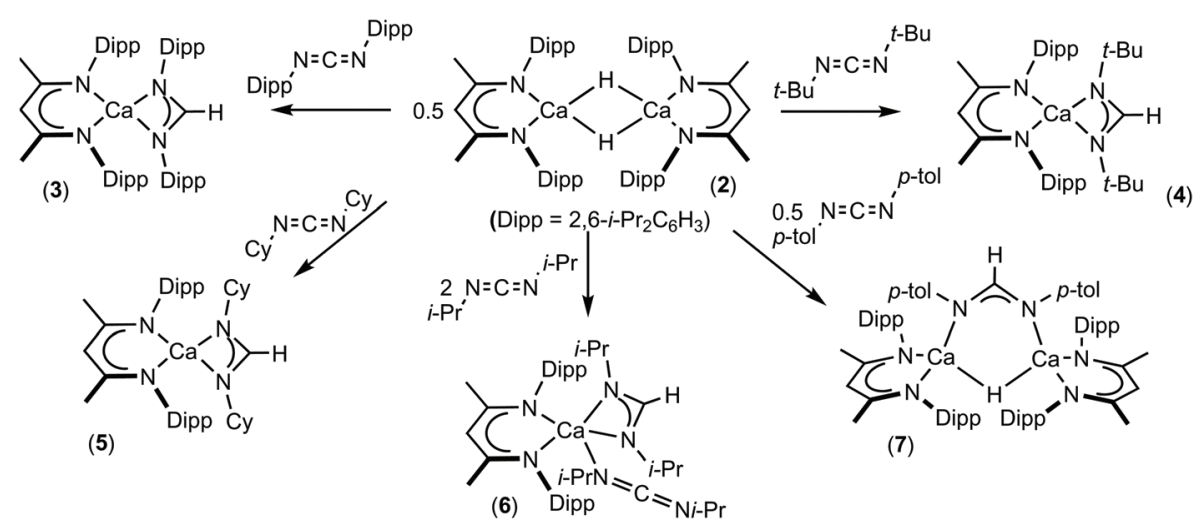

Scheme 2 Synthesis of compounds 3-7.

\section{Results and discussion}

An initial NMR scale reaction between compound 2 and $\operatorname{DippN}=\mathrm{C}=\mathrm{NDipp}$ afforded clean access to the expected formamidinate, [(BDI)Ca(DippNC(H)NDipp)] (3, Scheme 2). The formation of compound $\mathbf{3}$ was most clearly evidenced by the appearance of a diagnostic formamidinate methine singlet resonance at $\delta 8.07 \mathrm{ppm}$ that integrated $1 \mathrm{H}: 1 \mathrm{H}$ with a BDI $\gamma$-CH methine signal at $\delta 4.83 \mathrm{ppm}$ in the resultant ${ }^{1} \mathrm{H}$ NMR spectrum. Cooling a saturated pentane solution of 3 to $-35^{\circ} \mathrm{C}$ afforded single crystals from which its solid state structure was determined by X-ray diffraction analysis (Fig. 1).

The identity of the formamidinate anion in 3 is clearly indicated by the elongation of the $\mathrm{C} 30-\mathrm{N} 3$ and C30-N4 bonds [1.3250(16), 1.3217(16) $\mathrm{A}]$ and the narrowing of the N4-C30-N3 angle $\left[120.51(11)^{\circ}\right]$ in comparison to the respective measurements in the carbodiimide starting material [1.213(2), 1.221(2) $\AA$ and $\left.169.3(2)^{\circ}\right] .{ }^{57}$ Despite the steric constraints imposed by the flanking di-isopropylphenyl groups in both the formamidinate and BDI anions, Ca1 lies in a distorted pseudo-tetrahedral environment provided solely by the four nitrogen donors and is effectively coplanar with both of the ligands [Ca1 is displaced from the mean plane defined by N3, N4, C30 by $0.075 \AA$ and from N1, N2, C1, C2, C3, C4, C5 by $0.06 \AA] .{ }^{58}$ The planes defined by the chelated ligands are not orthogonal, however, and adopt a mutual orientation which is $49.49^{\circ}$ away from coplanarity. The $\mathrm{Ca}-\mathrm{N}$ distances to the formamidinate ligand [Ca1-N3 2.3877(10), Ca1-N4 2.3875(10) ̊] fall at the short end of the range reported for terminal calcium amidinates, $2.306(5)-2.525(3) \AA{ }^{27}$

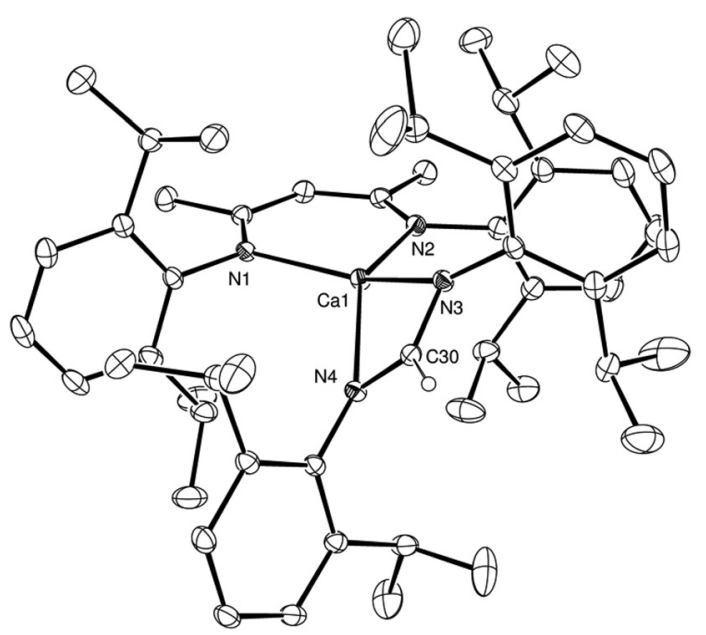

Fig. 1 ORTEP representation of compound 3 with thermal ellipsoids at 25\%. $\mathrm{H}$ atoms, except for the hydrogen attached to $\mathrm{C} 30$, have been removed for clarity. Selected bond distances (Å) and angles ( $\left(^{\circ}\right)$ : Ca1-N1 2.3551(10), Ca1-N2 2.3496(10), Ca1-N3 2.3877(10), Ca1-N4 2.3875(10), C30-N3 1.3250(16), C30-N4 1.3217(16), N1-Ca1-N2 81.21(4), N3-Ca1N4 57.53(3), N4-C30-N3 120.51(11).

The reactivity of compound 2 was then extended to the $\mathrm{N}, \mathrm{N}$ dialkylcarbodiimides, $t$ - $\mathrm{BuN}=\mathrm{C}=\mathrm{N} t$ - $\mathrm{Bu}$ and $\mathrm{CyN}=\mathrm{C}=\mathrm{NCy}$, to afford the corresponding formamidinate derivatives, [(BDI)Ca $(t$-BuNC $(\mathrm{H}) t-\mathrm{Bu})]$ and $[(\mathrm{BDI}) \mathrm{Ca}(\mathrm{CyNC}(\mathrm{H}) \mathrm{NCy})]$, compounds 4 and 5, respectively (Scheme 2). The formation of both 4 and 5 was again confirmed by the appearance of distinctive formamidinate methine resonances at $\delta 8.51$ and $8.08 \mathrm{ppm}$ in the resultant 
${ }^{1} \mathrm{H}$ NMR spectra. The structure of compound 4 was also determined by single crystal X-ray diffraction analysis of crystals grown from a saturated hexane solution at $-35^{\circ} \mathrm{C}$ (Fig. 2a).

In a similar manner to compound 3 , the formation of a formamidinate anion in 4 is indicated by the C34-N3 and C34N4 bonds [1.321(2), 1.322(2) $\AA$ ], which are in close correspondence with the analogous measurements of the previously reported tert-butyl formamidinate, $\left[\left(t\right.\right.$-BuNC(H)Nt-Bu) $\left.\left(\mathrm{B}\left\{\mathrm{C}_{6} \mathrm{~F}_{5}\right\}_{2}\right)\right]$ $[1.321(2), 1.314(2) \AA] .{ }^{13}$ While the calcium centre lies only $0.048 \AA$ out of the mean plane defined by N3, N4 and C30 and is, thus, effectively coplanar with the formamidinate anion, in contrast to compound $\mathbf{3}$ and presumably as a consequence of the differing steric demands of the $N$-alkyl substituents, the calcium centre resides some $1.37 \AA$ out of the N1, N2, C1, C2, $\mathrm{C} 3, \mathrm{C} 4, \mathrm{C} 5$ plane of the BDI ligand. As a result, albeit the four $\mathrm{Ca}-\mathrm{N}$ interactions [2.3462(11), 2.3420(11), 2.3242(13) and $2.3867(11) \AA]$ lie within the normal expected range, the two chelated ligands adopt an unusual relative disposition. Most notably, the angle between the mean planes containing [Ca1, N1, N2] and [N1, N2, C1, C2, C3, C4, C5] define an angle of $127.4^{\circ}$, which leaves the calcium centre exposed with what appears to be an otherwise vacant coordination site (Fig. 2b). No similar asymmetry of the formamidinate or BDI environments, however, could be discerned in the solution NMR spectra. We are, thus, satisfied to ascribe the unusual coordination environment of the calcium centre in the structure of 4 to a solid state packing effect.

Reduction of the steric bulk of the carbodiimide reaction partner to $i$-PrN $=\mathrm{C}=\mathrm{N} i$-Pr, also afforded the corresponding formamidinate, compound $\mathbf{6}$, as evidenced by the appearance of the formamidinate methine signal at $\delta 8.27 \mathrm{ppm}$ in its ${ }^{1} \mathrm{H}$ NMR spectrum. In this case, however, complete conversion to a single new product necessitated the use of two molar equivalents of the carbodiimide reagent. The origin of this observation was resolved through the crystallisation of compound 6, whereupon the resultant single crystal X-ray diffrac-

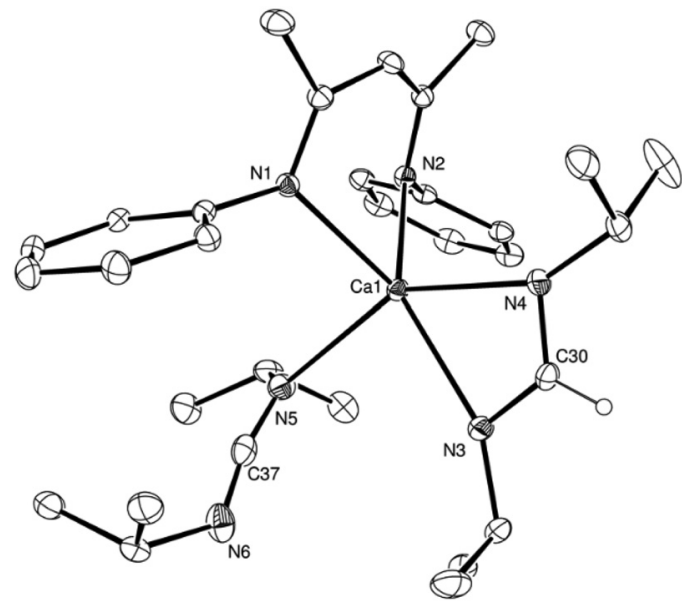

Fig. 3 ORTEP representation of compound 6 with thermal ellipsoids at $25 \%$. $\mathrm{H}$ atoms, except for the hydrogen attached to C30, have been removed for clarity. Selected bond lengths $(\AA)$ and bond angles $\left({ }^{\circ}\right)$. Ca1N1 2.352(2), Ca1-N2 2.3691(19), Ca1-N3 2.407(2), Ca1-N4 2.380(2), Ca1-N5 2.538(2), N3-C30 1.324(3), N4-C30 1.317(3), N5-C37 1.235(4), N6-C37 1.219(5), N1-Ca1-N2 81.17(7), N4-Ca1-N3 57.50(7), N1-Ca1N3 136.05(8), N1-Ca1-N4 107.04(7), N1-Ca1-N5 95.01(7), N2-Ca1-N3 141.17(8), N2-Ca1-N4 108.32(7), N2-Ca1-N5 98.19(7), N3-Ca1-N5 90.09(7), N4-C30-N3 121.3(2), N6-C37-N5 168.8(6).

tion analysis revealed that the formamidinate complex crystallises with the coordination of an equivalent of $i$ - $\mathrm{PrN}=\mathrm{C}=\mathrm{N} i$-Pr to afford a 5-coordinate calcium complex, $[(\mathrm{BDI}) \mathrm{Ca}(i \operatorname{PrNC}(\mathrm{H})$ $\mathrm{N} i \mathrm{Pr})(i$-PrNCNi-Pr)] (Fig. 3).

The C30-N3 and C30-N4 bonds [1.324(3), 1.317(3) ̊] and the N4-C30-N3 angle [121.3(2) $)^{\circ}$ in compound 6 are comparable with the corresponding measurements within Gordon's homoleptic calcium $N, N$-di-isopropyl formamidinate complex, $\left[(i \mathrm{PrNC}(\mathrm{H}) \mathrm{Ni} \mathrm{Pr})_{2} \mathrm{Ca}\right]_{2}, \quad[1.28(3)-1.328(6) \quad \AA \quad$ and $118.6(4)-$ 122.3(4) ${ }^{\circ} .{ }^{37}$ The calcium centre of 6 is five-coordinate with four nitrogen donor interactions provided by the formally
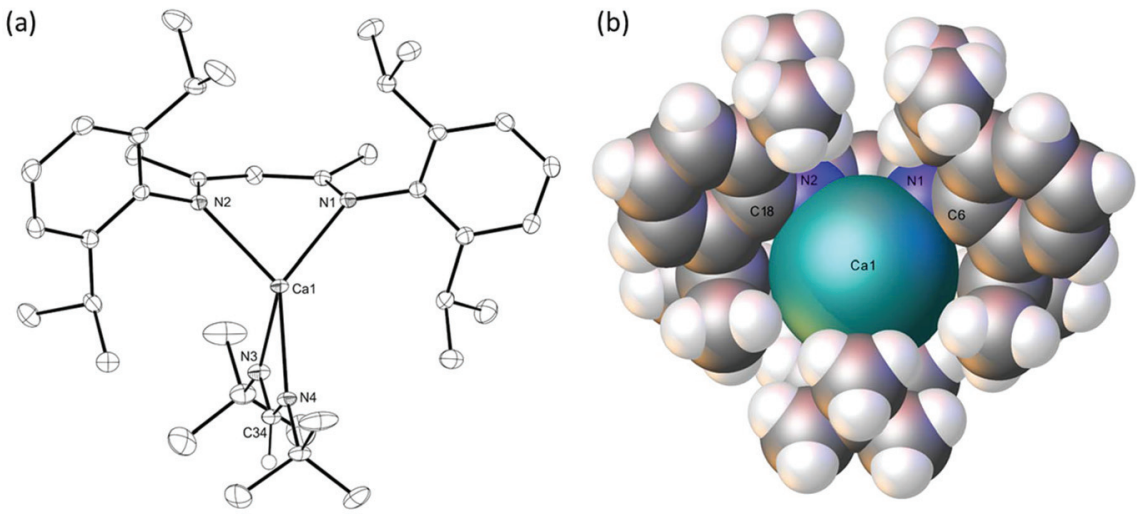

Fig. 2 (a) ORTEP representation of compound 4 with thermal ellipsoids at $25 \%$. Hexane solvent, disordered carbon atoms and $\mathrm{H}$ atoms, except for the hydrogen attached to $\mathrm{C} 34$, have been removed for clarity. (b) Space filling representation of compound 4 in the same orientation highlighting the exposed environment of the Ca1 centre. Selected bond distances (Å) and angles ( ${ }^{\circ}$ ): Ca1-N1 2.3462(11), Ca1-N2 2.3420(11), Ca1-N3 2.3242(13), Ca1-N4 2.3867(11), N3-C34 1.321(2), N4-C34 1.322(2), N2-Ca1-N1 82.56(4), N3-Ca1-N4 58.57(4), N1-Ca1-N4 139.47(4), N2-Ca1-N4 137.86(4), N3-Ca1-N1 116.83(4), N3-Ca1-N2 112.61(4), N3-C34-N4 121.42(13). 
anionic formamidinate and BDI ligands [2.352(2)-2.407(2) $\AA$ ]. The coordination sphere of the calcium is completed by a longer nitrogen interaction $[2.538(2) \AA]$ from the molecule of $i$ - $\mathrm{PrN}=\mathrm{C}=\mathrm{N} i$-Pr, that effectively occupies the 'open' coordination site of the calcium atom that was a notable feature of the structure of compound 4. This observation is underscored by a calculated $\tau_{5}$ value of 0.09 , which is indicative of a coordination geometry approaching square pyramidal with the N1 atom of the BDI ligand providing the apex of the pyramid. ${ }^{59}$

A further reaction at room temperature with the $N$-aryl carbodiimide, $p$-tolN $=\mathrm{C}=\mathrm{N} p$-tol, afforded a mixed formamidinate-hydride complex, $[\{\mathrm{BDI}\}(\mathrm{H})(p$-tolNC $(\mathrm{H}) \mathrm{N} p$-tol $)]$ (7, Scheme 2), irrespective of the reaction stoichiometry. The formation of compound 7 was clearly apparent from the appearance of unique formamidinate and BDI methine signals $(\delta 8.04,4.95 \mathrm{ppm})$, which were observed to emerge alongside a further singlet resonance that was assigned to the maintenance of a Ca-H environment at $\delta 4.41 \mathrm{ppm}$ and which integrated in a respective $1 \mathrm{H}: 2 \mathrm{H}: 1 \mathrm{H}$ ratio in the resultant ${ }^{1} \mathrm{H}$ NMR spectrum. The structure of compound 7 was confirmed by a further single crystal X-ray diffraction analysis of crystals formed by cooling a saturated hexane solution to $-35{ }^{\circ} \mathrm{C}$ (Fig. 4).

The asymmetric unit of compound 7 comprises two similar di-calcium molecules in which dimerization is propagated through a single amidinate anion, which spans both Ca centres, and a residual $\mu_{2}-\mathrm{Ca}-\mathrm{H}-\mathrm{Ca}$ bridging interaction. The C-N bonds [C37-N3 1.321(2), C37-N4 1.321(2), N9-C110 1.321(2), N10-C110 1.324(2) $\AA$ ] of the formamidinate anions within both entities of the asymmetric unit are closely comparable with the analogous measurements within the previously

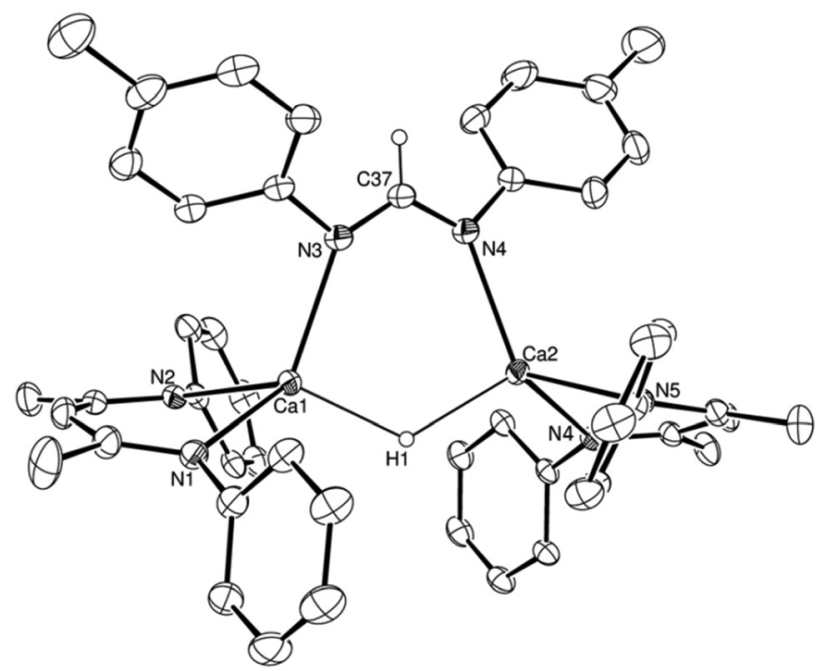

Fig. 4 ORTEP representation of the Ca1/Ca2-containing molecule in the asymmetric unit of compound 7 with thermal ellipsoids at $25 \%$. The $\mathrm{Ca} 3 / \mathrm{Ca} 4-$ containing molecule, $\mathrm{H}$ atoms, except for $\mathrm{H} 1$ and the hydrogen attached to $\mathrm{C} 37$, and i-Pr groups have been omitted for clarity. Selected bond distances $(\AA)$ and angles $\left({ }^{\circ}\right)$ : Ca1-N1 2.3289(11), Ca1-N2 2.3360(11), Ca1-N3 2.4055(12), Ca2-N4 2.4207(12), Ca2-N5 2.3485(11), Ca2-N6 2.3264(10), N3-C37 1.321(2), N4-C37 1.321(2), N1-Ca1-N2 80.57(4), N6-Ca2-N5 80.79(4), N4-C37-N3 124.82(13). reported magnesium complex of the same ligand, $[(p$-tolNC $(\mathrm{H})$ $\mathrm{N} p$-tol $\left.)_{2} \mathrm{Mg}(\mathrm{THF})_{2}\right][1.312(3)-1.323(3) \AA] .{ }^{60}$ In contrast, the chelating disposition adopted by the ligands about magnesium in this previously described complex subtend significantly narrower $\mathrm{N}-\mathrm{C}-\mathrm{N}$ angles $\left[116.0(3), 117.9(3)^{\circ}\right]$ than either of the bridging formamidinate anions in the structure of 7 [N4-C37N3, 124.82(13); N9-C110-N10 125.05(13) ${ }^{\circ}$. The bridging mode adopted also contrasts significantly with that observed in the only other amidinate-bridged calcium complexes, the aforementioned $\left[(i \mathrm{PrNC}(\mathrm{H}) \mathrm{N} i \mathrm{Pr})_{2} \mathrm{Ca}\right]_{2}$ and a similarly homoleptic species comprising a propargyl-substituted anion. ${ }^{37,61}$ Whereas the bridging amidinate nitrogen atoms in both of these previously reported species are 4-coordinate, engaging with both calcium centres in a $\mu_{2}-\mathrm{Ca}-\mathrm{N}-\mathrm{Ca}$ fashion, $\mathrm{N} 3$ and $\mathrm{N} 4$ within the structure of compound 7 interact solely with Ca1 and $\mathrm{Ca} 2$, respectively. Despite this reduction in the number of nitrogen-to-element bonds from 4 to 3 , the resultant Ca1-N3 and Ca2-N4 distances [2.4055(12), 2.4207(12) $\AA$ ] in 7 are not notably shorter than the ranges established previously [2.400(3)-2.650(3) $\AA$ ]. Both calcium centres, thus, reside in four-coordinate environments, which are completed by two $\mathrm{Ca}-\mathrm{N}$ interactions from the BDI ligands and the bridging hydride. Attempts to react the remaining hydride of compound 7 with a further equivalent of $p$-tolN $=\mathrm{C}=\mathrm{N} p$-tol at elevated temperatures were unsuccessful and merely resulted in ligand redistribution to various species, including the known bis$\beta$-diketiminate derivative, $\left[\mathrm{Ca}(\mathrm{BDI})_{2}\right]{ }^{62,63}$ We have previously noted that the reactivity of compound 2 with the $\mathrm{C}=\mathrm{C}$ bonds of terminal alkenes occurs with the retention of the relatively robust hydrido-bridged dimer. ${ }^{55,56}$ The formation of compounds 3-6 necessarily ensues with the generation of mononuclear calcium species, which is most likely a reflection of the significant steric bulk of the nitrogen-bound hydrocarbon residues. Notably, inspection of the resultant ${ }^{1} \mathrm{H}$ NMR spectrum immediately after addition of a single further equivalent of $i-\mathrm{PrN}=\mathrm{C}=\mathrm{N} i$-Pr to an isolated sample of compound 7 demonstrated the disappearance of the residual hydride resonance at $\delta 4.41 \mathrm{ppm}$ and the generation of an equimolar mixture of compound 6 and a new amidinate species, which we assign as the further amidinate complex $[(\mathrm{BDI}) \mathrm{Ca}(p$-tolNC $(\mathrm{H}) \mathrm{N} p$-tol)] (Fig. S11 $\dagger$ ). Although not pursued further, we, thus, tentatively suggest that the dinuclear constitution of compound 7 is a consequence of both the reduced steric demands of the $N$ - $p$-tolyl substituents and the lower basicity of $p$-tolN $=\mathrm{C}=\mathrm{N} p$-tol. The consequent inability of a single equivalent of $p$-tolyl carbodiimide to induce dimer fragmentation during the initial insertion process, thus, restricts access to the remaining $\mathrm{Ca}-\mathrm{H}$ bond.

In conclusion, reactions between the dimeric calcium hydride, $[(\mathrm{BDI}) \mathrm{CaH}]_{2}$ and representative carbodimide small molecules are facile and result in the generation of welldefined formamidinate products. X-ray crystallographic studies reveal that the resultant calcium coordination environments and coordination numbers are strongly dependent upon the relative steric demands of the $\mathrm{N}$-aryl or $\mathrm{N}$-alkyl substituents. 


\section{Experimental details}

\section{General considerations and starting materials}

All manipulations were carried out using standard Schlenk line and glovebox techniques under an inert atmosphere of argon. NMR experiments were conducted in J Young tap NMR tubes prepared and sealed in a Glovebox. NMR spectra were collected on a Bruker AV300 spectrometer operating at 300.2 MHz $\left({ }^{1} \mathrm{H}\right)$, 75.5 MHz $\left({ }^{13} \mathrm{C}\right)$ or an Agilent ProPulse spectrometer operating at $500 \mathrm{MHz}\left({ }^{1} \mathrm{H}\right), 126 \mathrm{MHz}\left({ }^{13} \mathrm{C}\right)$. The spectra were referenced relative to residual protio solvent resonances. Solvents (toluene, hexane, pentane) were dried by passage through a commercially available (MBraun) solvent purification system, under nitrogen and stored in ampoules over $4 \AA$ molecular sieves. $\mathrm{C}_{6} \mathrm{D}_{6}$ was purchased from Sigma-Aldrich Corp., dried over a potassium mirror before vacuum distilling under argon and storing over molecular sieves. Calcium iodide (99.95\%) and carbodiimide reagents were purchased from Sigma-Aldrich Corp. and used without further purification. $[(\mathrm{BDI}) \mathrm{CaH}]_{2}$ (2) was synthesised by a literature procedure. ${ }^{55}$

\section{[(BDI)Ca(DippNC(H)NDipp)] (3)}

Toluene $(10 \mathrm{ml})$ was added to $2(0.92 \mathrm{~g}, 1.00 \mathrm{mmol})$ and $\operatorname{DippN}=\mathrm{C}=\mathrm{NDipp}(0.73 \mathrm{~g}, 2.01 \mathrm{mmol})$ then stirred overnight at room temperature. The resulting solution was evaporated to dryness, redissolved in pentane $(10 \mathrm{ml})$, cannula filtered and concentrated. Colourless crystals were deposited overnight at $-35{ }^{\circ} \mathrm{C}$ and collected via cannula filtration to yield compound 3. $(0.94 \mathrm{~g}, 57 \%) .{ }^{1} \mathrm{H}$ NMR (500 MHz, benzene-d $\left.\mathrm{d}_{6}\right) \delta 8.07(\mathrm{~s}, 1 \mathrm{H}$, $\mathrm{NC}(H) \mathrm{N}), 7.06-6.98(\mathrm{~m}, 12 \mathrm{H}, \mathrm{Ar}-H), 4.83\left(\mathrm{~s}, 1 \mathrm{H}, \mathrm{NC}\left(\mathrm{CH}_{3}\right) \mathrm{CH}\right)$, 3.20 (hept, $\left.{ }^{3} J_{\mathrm{HH}}=6.8 \mathrm{~Hz}, 4 \mathrm{H}, \mathrm{CH}\left(\mathrm{CH}_{3}\right)_{2}\right), 3.04$ (hept, ${ }^{3} J_{\mathrm{HH}}=6.8$ $\left.\mathrm{Hz}, 4 \mathrm{H}, \mathrm{CH}\left(\mathrm{CH}_{3}\right)_{2}\right), 1.58\left(\mathrm{~s}, 6 \mathrm{H}, \mathrm{NC}\left(\mathrm{CH}_{3}\right) \mathrm{CH}\right), 1.17\left(\mathrm{~d},{ }^{3} J_{\mathrm{HH}}=\right.$ $\left.6.8 \mathrm{~Hz}, 12 \mathrm{H}, \mathrm{CH}\left(\mathrm{CH}_{3}\right)_{2}\right), 1.12\left(\mathrm{~d},{ }^{3} \mathrm{~J}_{\mathrm{HH}}=6.8 \mathrm{~Hz}, 12 \mathrm{H}, \mathrm{CH}\right.$ $\left.\left(\mathrm{CH}_{3}\right)_{2}\right), 1.05\left(\mathrm{~d},{ }^{3} J_{\mathrm{HH}}=6.8 \mathrm{~Hz}, 24 \mathrm{H}, \mathrm{CH}\left(\mathrm{CH}_{3}\right)_{2}\right) \mathrm{ppm} .{ }^{13} \mathrm{C}\left\{{ }^{1} \mathrm{H}\right\}$ NMR $\left(126 \mathrm{MHz}\right.$, benzene- $\left.d_{6}\right) \delta 170.0(\mathrm{NC}(\mathrm{H}) \mathrm{N}), 167.5\left(\mathrm{NC}\left(\mathrm{CH}_{3}\right)\right.$ $\mathrm{CH}), 146.5,145.8$ ( $\left.C_{\text {ipso }}\right), 141.8,141.7$ ( $\left.C_{\text {ortho }}\right), 125.3,124.2$ $\left(C_{\text {para }}\right), 123.4,123.3\left(C_{\text {meta }}\right), 94.1\left(\mathrm{NC}\left(\mathrm{CH}_{3}\right) \mathrm{CH}\right), 28.9,28.8(\mathrm{CH}$ $\left.\left(\mathrm{CH}_{3}\right)_{2}\right), 25.3\left(\mathrm{CH}\left(\mathrm{CH}_{3}\right)_{2}\right), 24.9\left(\mathrm{NC}\left(\mathrm{CH}_{3}\right) \mathrm{CH}\right), 24.4,24.0(\mathrm{CH}$ $\left.\left(\mathrm{CH}_{3}\right)_{2}\right)$ ppm. Elemental analysis for $\mathrm{C}_{54} \mathrm{H}_{76} \mathrm{CaN}_{4}$ : C, 78.97; $\mathrm{H}$, 9.33; N, 6.82\%. Found: C, 78.81; H, 9.48, N, 6.73\%.

\section{$[(\mathrm{BDI}) \mathrm{Ca}(t$-BuNC(H)t-Bu)] (4)}

Toluene $(10 \mathrm{ml})$ was added to $2(0.92 \mathrm{~g}, 1.00 \mathrm{mmol})$ and $t \mathrm{BuN}=\mathrm{C}=\mathrm{N} t \mathrm{Bu}(386 \mu \mathrm{l}, 2.00 \mathrm{mmol})$ then stirred at room temperature for $c a$. 1 hour. The resulting solution was evaporated to dryness, redissolved in hexane $(10 \mathrm{ml})$, cannula filtered and concentrated. Colourless crystals were deposited overnight at $-35{ }^{\circ} \mathrm{C}$ and collected via cannula filtration to yield compound 4. (0.55 g, 45\%). ${ }^{1} \mathrm{H}$ NMR (500 MHz, benzene- $\left.d_{6}\right) \delta 8.51$ $(\mathrm{s}, 1 \mathrm{H}, \mathrm{NC}(H) \mathrm{N}), 7.21-7.11(\mathrm{~m}, 6 \mathrm{H}, \mathrm{Ar}-H), 4.87\left(\mathrm{~s}, 1 \mathrm{H}, \mathrm{NC}\left(\mathrm{CH}_{3}\right)\right.$ $\mathrm{CH}$ ), 3.26 (hept, $\left.{ }^{3} \mathrm{~J}_{\mathrm{HH}}=6.8 \mathrm{~Hz}, 4 \mathrm{H}, \mathrm{CH}\left(\mathrm{CH}_{3}\right)_{2}\right), 1.74(\mathrm{~s}, 6 \mathrm{H}, \mathrm{NC}$ $\left.\left(\mathrm{CH}_{3}\right) \mathrm{CH}\right), 1.29\left(\mathrm{~d},{ }^{3} \mathrm{~J}_{\mathrm{HH}}=6.8 \mathrm{~Hz}, 12 \mathrm{H}, \mathrm{CH}\left(\mathrm{CH}_{3}\right)_{2}\right), 1.27\left(\mathrm{~d},{ }^{3} \mathrm{~J}_{\mathrm{HH}}\right.$ $\left.=6.8 \mathrm{~Hz}, 12 \mathrm{H}, \mathrm{CH}\left(\mathrm{CH}_{3}\right)_{2}\right), 0.99\left(\mathrm{~s}, 18 \mathrm{H}, \mathrm{NC}\left(\mathrm{CH}_{3}\right)_{3}\right) \mathrm{ppm} \cdot{ }^{13} \mathrm{C}$ $\left\{{ }^{1} \mathrm{H}\right\}$ NMR (126 MHz, benzene- $\left.d_{6}\right) \delta 166.1\left(\mathrm{NC}\left(\mathrm{CH}_{3}\right) \mathrm{CH}\right), 164.3$ $(\mathrm{NC}(\mathrm{H}) \mathrm{N}), 146.8$ ( $\left.C_{\text {ipso }}\right), 141.4$ (C $\left.C_{\text {ortho }}\right), 124.6\left(C_{\text {para }}\right), 123.9$ $\left(C_{\text {meta }}\right), 91.4\left(\mathrm{NC}\left(\mathrm{CH}_{3}\right) C \mathrm{H}\right), 51.3\left(\mathrm{NC}\left(\mathrm{CH}_{3}\right)_{3}\right), 32.5\left(\mathrm{NC}\left(\mathrm{CH}_{3}\right)_{3}\right)$,
$28.8\left(\mathrm{CH}\left(\mathrm{CH}_{3}\right)_{2}\right), 25.8\left(\mathrm{CH}\left(\mathrm{CH}_{3}\right)_{2}\right), 24.8\left(\mathrm{NC}\left(\mathrm{CH}_{3}\right) \mathrm{CH}\right), 24.3(\mathrm{CH}$ $\left.\left(\mathrm{CH}_{3}\right)_{2}\right)$ ppm. Elemental analysis for $\mathrm{C}_{38} \mathrm{H}_{60} \mathrm{CaN}_{4}$ : C, 74.46; $\mathrm{H}$, 9.87; N, 9.14\%. Found: C, 74.21; H, 9.98, N, 9.22\%.

\section{[(BDI)Ca(CyNC(H)NCy)] (5)}

Toluene $(10 \mathrm{ml})$ was added to $2(0.92 \mathrm{~g}, 1.00 \mathrm{mmol})$ and $\mathrm{CyN}=\mathrm{C}=\mathrm{NCy}(0.41 \mathrm{~g}, 1.99 \mathrm{mmol})$ then stirred at room temperature for $c a$. 1 hour. The resulting solution was evaporated to dryness, redissolved in hexane $(10 \mathrm{ml})$, cannula filtered and concentrated. Colourless crystals were deposited overnight at $-35^{\circ} \mathrm{C}$ and collected via cannula filtration to yield compound 5. $(0.62 \mathrm{~g}, 47 \%) .{ }^{1} \mathrm{H}$ NMR (500 MHz, benzene-d $\left.\mathrm{d}_{6}\right) \delta 8.08(\mathrm{~s}, 1 \mathrm{H}$, $\mathrm{NC}(H) \mathrm{N}), 7.18-7.11(\mathrm{~m}, 6 \mathrm{H}, \mathrm{Ar}-H), 4.94\left(\mathrm{~s}, 1 \mathrm{H}, \mathrm{NC}\left(\mathrm{CH}_{3}\right) \mathrm{CH}\right)$, 3.29 (hept, $\left.{ }^{3} \mathrm{JHH}_{\mathrm{HH}}=6.8 \mathrm{~Hz}, 4 \mathrm{H}, \mathrm{CH}\left(\mathrm{CH}_{3}\right)_{2}\right), 2.57-2.51(\mathrm{~m}, 2 \mathrm{H}$, $\left.\mathrm{NCH}\left(\mathrm{CH}_{2}\right)_{5}\right), 1.77\left(\mathrm{~s}, 6 \mathrm{H}, \mathrm{NC}\left(\mathrm{CH}_{3}\right) \mathrm{CH}\right), 1.72-1.64(\mathrm{~m}, 4 \mathrm{H}, \mathrm{NCH}$ $\left.\left(\mathrm{CH}_{2}\right)_{5}\right), 1.61-1.54\left(\mathrm{~m}, 4 \mathrm{H}, \mathrm{NCH}\left(\mathrm{CH}_{2}\right)_{5}\right), 1.51-1.43(\mathrm{~m}, 4 \mathrm{H}, \mathrm{NCH}$ $\left.\left(\mathrm{CH}_{2}\right)_{5}\right), 1.29\left(\mathrm{~d},{ }^{3} J_{\mathrm{HH}}=6.8 \mathrm{~Hz}, 12 \mathrm{H}, \mathrm{CH}\left(\mathrm{CH}_{3}\right)_{2}\right), 1.26\left(\mathrm{~d},{ }^{3} J_{\mathrm{HH}}=\right.$ $\left.6.8 \mathrm{~Hz}, 12 \mathrm{H}, \mathrm{CH}\left(\mathrm{CH}_{3}\right)_{2}\right), 1.14-1.03\left(\mathrm{~m}, 4 \mathrm{H}, \mathrm{NCH}\left(\mathrm{CH}_{2}\right)_{5}\right)$, 0.92-0.81(m, 4H, NCH( $\left.\left(\mathrm{CH}_{2}\right)_{5}\right)$ ppm. ${ }^{13} \mathrm{C}\left\{{ }^{1} \mathrm{H}\right\}$ NMR $(126 \mathrm{MHz}$, benzene- $\left.d_{6}\right) \quad \delta \quad 168.7(\mathrm{~N} C(\mathrm{H}) \mathrm{N}), 165.9\left(\mathrm{NC}\left(\mathrm{CH}_{3}\right) \mathrm{CH}\right), 146.4$ $\left(C_{\text {ipso }}\right), 141.5\left(C_{\text {ortho }}\right), 124.6\left(C_{\text {para }}\right), 124.1\left(C_{\text {meta }}\right), 93.0\left(\mathrm{NC}\left(\mathrm{CH}_{3}\right)\right.$ $\mathrm{CH}), 61.7\left(\mathrm{NCH}\left(\mathrm{CH}_{2}\right)_{5}\right), 37.2\left(\mathrm{NCH}\left(\mathrm{CH}_{2}\right)_{5}\right), 28.7\left(\mathrm{CH}\left(\mathrm{CH}_{3}\right)_{2}\right)$, 26.4, $26.3\left(\mathrm{NCH}\left(\mathrm{CH}_{2}\right)_{5}\right), 25.6\left(\mathrm{CH}\left(\mathrm{CH}_{3}\right)_{2}\right), 24.5\left(\mathrm{NC}\left(\mathrm{CH}_{3}\right) \mathrm{CH}\right)$, $24.3\left(\mathrm{CH}\left(\mathrm{CH}_{3}\right)_{2}\right)$ ppm. Elemental analysis for $\mathrm{C}_{42} \mathrm{H}_{64} \mathrm{CaN}_{4}: \mathrm{C}$, 75.85; H, 9.70; N, 8.42\%. Found: C, 75.71; H, 9.87, N, 8.37\%.

\section{[(BDI)Ca(iPrNC(H)NiPr)(iPrNCNiPr)] (6)}

Toluene $(10 \mathrm{ml})$ was added to $2(0.92 \mathrm{~g}, 1.00 \mathrm{mmol})$ and $i$ PrNCNiPr $(621 \mu \mathrm{l}, 4.01 \mathrm{mmol})$ then stirred at room temperature for $c a$. 1 hour. The resulting solution was evaporated to dryness, redissolved in hexane $(10 \mathrm{ml})$, cannula filtered and concentrated. Colourless crystals were deposited overnight at $-35{ }^{\circ} \mathrm{C}$ and collected via cannula filtration to yield compound 6. $(0.56 \mathrm{~g}, 39 \%) .{ }^{1} \mathrm{H}$ NMR (500 MHz, benzene- $\left.d_{6}\right) \delta 8.27(\mathrm{~s}, 1 \mathrm{H}$, $\mathrm{NC}(H) \mathrm{N}), 7.18-7.07(\mathrm{~m}, 6 \mathrm{H}, \mathrm{Ar}-H), 4.92\left(\mathrm{~s}, 1 \mathrm{H}, \mathrm{NC}\left(\mathrm{CH}_{3}\right) \mathrm{CH}\right)$, 3.44 (hept, $\left.{ }^{3} J_{\mathrm{HH}}=6.8 \mathrm{~Hz}, 4 \mathrm{H}, \mathrm{CH}\left(\mathrm{CH}_{3}\right)_{2}\right), 3.14$ (hept, ${ }^{3} J_{\mathrm{HH}}=6.4$ $\left.\mathrm{Hz}, 2 \mathrm{H}, \mathrm{NC}(\mathrm{H}) \mathrm{N}\left\{\mathrm{CH}\left(\mathrm{CH}_{3}\right)_{2}\right\}_{2}\right), 3.09$ (hept, ${ }^{3} \mathrm{~J}_{\mathrm{HH}}=6.4 \mathrm{~Hz}, 2 \mathrm{H}$, $\left.\mathrm{NCN}\left\{\mathrm{CH}\left(\mathrm{CH}_{3}\right)_{2}\right\}_{2}\right) 1.76\left(\mathrm{~s}, 6 \mathrm{H}, \mathrm{NC}\left(\mathrm{CH}_{3}\right) \mathrm{CH}\right), 1.32\left(\mathrm{~d},{ }^{3} \mathrm{~J}_{\mathrm{HH}}=6.8\right.$ $\left.\mathrm{Hz}, 12 \mathrm{H}, \mathrm{CH}\left(\mathrm{CH}_{3}\right)_{2}\right), 1.29\left(\mathrm{~d},{ }^{3} J_{\mathrm{HH}}=6.8 \mathrm{~Hz}, 12 \mathrm{H}, \mathrm{CH}\left(\mathrm{CH}_{3}\right)_{2}\right)$, $1.09\left(\mathrm{~d},{ }^{3} \mathrm{~J}_{\mathrm{HH}}=6.4 \mathrm{~Hz}, 12 \mathrm{H}, \mathrm{NC}(\mathrm{H}) \mathrm{N}\left\{\mathrm{CH}\left(\mathrm{CH}_{3}\right)_{2}\right\}_{2}\right), 0.86(\mathrm{~d}$, $\left.{ }^{3} J_{\mathrm{HH}}=6.4 \mathrm{~Hz}, 12 \mathrm{H}, \operatorname{NCN}\left\{\mathrm{CH}\left(\mathrm{CH}_{3}\right)_{2}\right\}_{2}\right) \mathrm{ppm} .{ }^{13} \mathrm{C}\left\{{ }^{1} \mathrm{H}\right\} \mathrm{NMR}$ $\left(126 \mathrm{MHz}\right.$, benzene- $\left.d_{6}\right) \delta 169.0(\mathrm{NC}(\mathrm{H}) \mathrm{N}), 165.4\left(\mathrm{NC}\left(\mathrm{CH}_{3}\right) \mathrm{CH}\right)$, $148.0\left(C_{\text {ipso }}\right), 141.8\left(C_{\text {ortho }}\right), 124.1\left(C_{\text {para }}\right), 123.8\left(C_{\text {meta }}\right), 93.6(\mathrm{NC}$ $\left.\left(\mathrm{CH}_{3}\right) \mathrm{CH}\right), 53.9\left(\mathrm{NC}(\mathrm{H}) \mathrm{N}\left\{\mathrm{CH}\left(\mathrm{CH}_{3}\right)_{2}\right\}_{2}\right), 49.5\left(\mathrm{NCN}\left\{\mathrm{CH}\left(\mathrm{CH}_{3}\right)_{2}\right\}_{2}\right)$, $28.3\left(\mathrm{CH}\left(\mathrm{CH}_{3}\right)_{2}\right), 26.8\left(\mathrm{NC}(\mathrm{H}) \mathrm{N}\left\{\mathrm{CH}\left(\mathrm{CH}_{3}\right)_{2}\right\}_{2}\right), 25.8\left(\mathrm{CH}\left(\mathrm{CH}_{3}\right)_{2}\right)$, $24.9\left(\mathrm{NC}\left(\mathrm{CH}_{3}\right) \mathrm{CH}\right), 24.6\left(\mathrm{CH}\left(\mathrm{CH}_{3}\right)_{2}\right), 24.2\left(\mathrm{NCN}\left\{\mathrm{CH}\left(\mathrm{CH}_{3}\right)_{2}\right\}_{2}.\right)$ ppm. Elemental analysis for $\mathrm{C}_{43} \mathrm{H}_{70} \mathrm{CaN}_{6}$ : C, 72.62; H, 9.92; N, $11.82 \%$. Found: C, 72.43; H, 9.95, N, 11.69\%.

\section{$\left[\{(\mathrm{BDI}) \mathrm{Ca}\}_{2}(\mathrm{H})(p\right.$-tolNC(H)N $p$-tol $\left.)\right](7)$}

Toluene $(10 \mathrm{ml})$ was added to $2(0.92 \mathrm{~g}, 1.00 \mathrm{mmol})$ and $p$-tolNCNp-tol $(0.22 \mathrm{~g}, 0.99 \mathrm{mmol})$ then stirred at room temperature for $c a$. 1 hour. The resulting solution was evaporated to dryness, redissolved in hexane $(10 \mathrm{ml})$, cannula filtered and concentrated. Colourless crystals were deposited overnight at $-35{ }^{\circ} \mathrm{C}$ and collected via cannula filtration to yield compound 
7. (0.60 g, 53\%). ${ }^{1} \mathrm{H}$ NMR (500 MHz, benzene-d $\left.{ }_{6}\right) \delta 8.04(\mathrm{~s}, 1 \mathrm{H}$, $\mathrm{NC}(H) \mathrm{N}), 7.15-7.05(\mathrm{~m}, 16 \mathrm{H}, \mathrm{Ar}-H), 6.91-6.89$ (m, 4H, Ar-H), 4.95 (s, 2H, $\left.\mathrm{NC}\left(\mathrm{CH}_{3}\right) \mathrm{CH}\right), 4.41(\mathrm{~s}, 1 \mathrm{H}, \mathrm{CaH}), 3.25-2.77$ (br, $8 \mathrm{H}$, $\left.\mathrm{CH}\left(\mathrm{CH}_{3}\right)_{2}\right), 2.11\left(\mathrm{~s}, 6 \mathrm{H}, \mathrm{NC}_{6} \mathrm{H}_{4} \mathrm{CH}_{3}\right), 1.66\left(\mathrm{~s}, 12 \mathrm{H}, \mathrm{NC}\left(\mathrm{CH}_{3}\right) \mathrm{CH}\right)$, 1.23-0.71 (br, 48H, CH(CH $\left.\mathrm{CH}_{2}\right)$ ppm. ${ }^{13} \mathrm{C}\left\{{ }^{1} \mathrm{H}\right\}$ NMR $(126 \mathrm{MHz}$, benzene- $\left.d_{6}\right) \quad \delta \quad 166.4\left(\mathrm{NC}\left(\mathrm{CH}_{3}\right) \mathrm{CH}\right), 166.1(\mathrm{NC}(\mathrm{H}) \mathrm{N}), 149.3$ (p-tol $\left.C_{i p s o}\right), 144.3\left(C_{\text {ipso }}\right), 142.3\left(C_{\text {ortho }}\right), 131.9$ ( $p$-tol $\left.C_{\text {para }}\right), 130.9$ $\left(C_{\text {para }}\right), 124.9$ (p-tol $\left.C\right), 124.1\left(C_{\text {meta }}\right), 120.5$ (p-tol $\left.C\right), 94.3(\mathrm{NC}$ $\left.\left(\mathrm{CH}_{3}\right) \mathrm{CH}\right), 28.4\left(\mathrm{CH}\left(\mathrm{CH}_{3}\right)_{2}\right), 25.2\left(\mathrm{CH}\left(\mathrm{CH}_{3}\right)_{2}\right), 24.2\left(\mathrm{NC}\left(\mathrm{CH}_{3}\right)\right.$ $\mathrm{CH}), 24.2\left(\mathrm{CH}\left(\mathrm{CH}_{3}\right)_{2}\right), 20.6\left(\mathrm{NC}_{6} \mathrm{H}_{4} \mathrm{CH}_{3}\right)$ ppm. Elemental analysis for $\mathrm{C}_{73} \mathrm{H}_{98} \mathrm{CaN}_{6}$ : C, 76.93; $\mathrm{H}, 8.67 ; \mathrm{N}, 7.37 \%$. Found: $\mathrm{C}$, 76.80; H, 8.87, N, 7.48\%.

\section{Conflicts of interest}

There are no conflicts of interest to declare.

\section{Acknowledgements}

We thank the EPSRC (UK) for the provision of a DTP studentship (ASSW) and the University of Bath.

\section{References}

1 (a) F. T. Edelmann, in Adv. Organometal. Chem, ed. A. F. Hill and M. J. Fink, 2013, vol. 61, pp. 55-374; (b) F. T. Edelmann, Adv. Organometal. Chem., 2008, vol. 57, 183-352.

2 J. Barker and M. Kilner, Coord. Chem. Rev., 1994, 133, 219.

3 E. Lu, Y. Chen and X. Leng, Organometallics, 2011, 30, 5433-5441.

4 Z. Jian, N. K. Hangaly, W. Rong, Z. Mou, D. Liu, S. Li, A. A. Trifonov, J. Sundermeyer and D. Cui, Organometallics, 2012, 31, 4579-4587.

5 B. M. Schmiege, M. E. Fieser, J. W. Ziller and W. J. Evans, Organometallics, 2012, 31, 5591-5598.

6 C. Wang, L. Xiang, X. Leng and Y. Chen, Dalton Trans., 2017, 46, 1218-1227.

7 J. Cheng and Z. Hou, Chem. Commun., 2012, 48, 814-816.

8 Y. Yu, A. R. Sadique, J. M. Smith, T. R. Dugan, R. E. Cowley, W. W. Brennessel, C. J. Flaschenriem, E. Bill, T. R. Cundari and P. L. Holland, J. Am. Chem. Soc., 2008, 130, 6624-6638.

9 S. Gambarotta, S. Strologo, C. Floriani, A. Chiesi-Villa and C. Guastini, J. Am. Chem. Soc., 1985, 107, 6278-6282.

10 J. F. Leboeuf, J. C. Leblanc and C. Moïse, J. Organomet. Chem., 1987, 335, 331-337.

11 G. Albertin, S. Antoniutti and G. Roveda, Inorg. Chim. Acta, 2005, 358, 3093-3105.

12 R. Boese, R. Köster and M. Yalpani, Z. Naturforsch., B: J. Chem. Sci., 1994, 49, 1453.

13 M. A. Dureen and D. W. Stephan, J. Am. Chem. Soc., 2010, 132, 13559-13568.

14 Y. Yuan, X. Wang, Y. Li, L. Fan, X. Xu, Y. Chen, G. Li and W. Xia, Organometallics, 2011, 30, 4330-4341.
15 C. Wang, X. Leng and Y. Chen, Organometallics, 2015, 34, 3216-3221.

16 M. L. Cole, C. Jones, C. Junk Peter, M. Kloth and A. Stasch, Chem. - Eur. J., 2005, 11, 4482-4491.

17 J. Hellmann, I. Rhotert, H. Westenberg, R. Fröhlich, B. Wibbeling, W. Uhl and E. U. Würthwein, Eur. J. Org. Chem., 2013, 3356-3368.

18 S. Schulz, T. Eisenmann, S. Schmidt, D. Blaser, U. Westphal and R. Boese, Chem. Commun., 2010, 46, 7226-7228.

19 G. Bendt, S. Schulz, J. Spielmann, S. Schmidt, D. Bläser and C. Wölper, Eur. J. Inorg. Chem., 2012, 3725-3731.

20 A. Rit, P. Spaniol Thomas and J. Okuda, Chem. - Asian J., 2014, 9, 612-619.

21 A. W. Jana, H. C. Roesky, C. Schulzke and A. Döring, Angew. Chem., Int. Ed., 2009, 48, 1106-1109.

22 A. Stasch, Dalton Trans., 2014, 43, 7078-7086.

23 S. J. Bonyhady, S. P. Green, C. Jones, S. Nembenna and A. Stasch, Angew. Chem., Int. Ed., 2009, 48, 2973-2977.

24 C. Weetman, M. S. Hill and M. F. Mahon, Chem. - Eur. J., 2016, 22, 7158-7162.

25 M. Westerhausen and W. Schwarz, Z. Naturforsch., B: J. Chem. Sci., 1992, 47, 453-459.

26 H. F. Hu and C. M. Cui, Organometallics, 2012, 31, 12081211.

27 C. Glock, C. Loh, H. Görls, S. Krieck and M. Westerhausen, Eur. J. Inorg. Chem., 2013, 3261-3269.

28 C. Loh, S. Seupel, H. Görls, S. Krieck and M. Westerhausen, Eur. J. Inorg. Chem., 2014, 2014, 1312-1321.

29 C. Loh, S. Seupel, H. Görls, S. Krieck and M. Westerhausen, Organometallics, 2014, 33, 1480-1491.

30 C. Loh, S. Seupel, A. Koch, H. Görls, S. Krieck and M. Westerhausen, Dalton Trans., 2014, 43, 14440-14449.

31 M. He, M. T. Gamer and P. W. Roesky, Organometallics, 2016, 35, 2638-2644.

32 A. Causero, G. Ballmann, J. Pahl, H. Zijlstra, C. Farber and S. Harder, Organometallics, 2016, 35, 3350-3360.

33 A. G. M. Barrett, M. R. Crimmin, M. S. Hill, P. B. Hitchcock, S. L. Lomas, M. F. Mahon, P. A. Procopiou and K. Suntharalingam, Organometallics, 2008, 27, 6300-6306.

34 M. Arrowsmith, M. R. Crimmin, M. S. Hill, S. L. Lomas, D. J. MacDougall and M. F. Mahon, Organometallics, 2013, 32, 4961-4972.

35 M. L. Cole and P. C. Junk, New J. Chem., 2005, 29, 135-140.

36 M. L. Cole, G. B. Deacon, C. M. Forsyth, K. Konstas and P. C. Junk, Dalton Trans., 2006, 3360-3367.

37 B. Kim Sang, C. Yang, T. Powers, M. Davis Luke, X. Lou and G. Gordon Roy, Angew. Chem., Int. Ed., 2016, 55, 10228-10233.

38 D. Mukherjee, D. Schuhknecht and J. Okuda, Angew. Chem., Int. Ed., 2018, 57, 9590-9602.

39 S. Harder, Chem. Commun., 2012, 48, 11165-11177.

40 S. Harder and J. Brettar, Angew. Chem., Int. Ed., 2006, 45, 3474-3478.

41 J. Spielmann and S. Harder, Chem. - Eur. J., 2007, 13, 8928-8938.

42 V. Leich, T. P. Spaniol and J. Okuda, Inorg. Chem., 2015, 54, 4927-4933. 
43 V. Leich, T. P. Spaniol, L. Maron and J. Okuda, Angew. Chem., Int. Ed., 2016, 55, 4794-4797.

44 A. Causero, G. Ballmann, J. Pahl, C. Farber, J. Intemann and S. Harder, Dalton Trans., 2017, 46, 1822-1831.

45 A. Causero, H. Elsen, J. Pahl and S. Harder, Angew. Chem., Int. Ed., 2017, 56, 6906-6910.

46 D. Schuhknecht, C. Lhotzky, T. P. Spaniol, L. Maron and J. Okuda, Angew. Chem., Int. Ed., 2017, 56, 12367-12371.

47 B. Maitland, M. Wiesinger, J. Langer, G. Ballmann, J. Pahl, H. Elsen, C. Farber and S. Harder, Angew. Chem., Int. Ed., 2017, 56, 11880-11884.

48 H. Bauer, M. Alonso, C. Farber, H. Elsen, J. Pahl, A. Causero, G. Ballmann, F. De Proft and S. Harder, Nat. Catal., 2018, 1, 40-47.

49 M. D. Anker, C. E. Kefalidis, Y. Yang, J. Fang, M. S. Hill, M. F. Mahon and L. Maron, J. Am. Chem. Soc., 2017, 139, 10036-10054.

50 J. Spielmann and S. Harder, Eur. J. Inorg. Chem., 2008, 1480-1486.

51 J. Intemann, H. Bauer, J. Pahl, L. Maron and S. Harder, Chem. - Eur. J., 2015, 21, 11452-11461.

52 D. Mukherjee, T. Hollerhage, V. Leich, T. P. Spaniol, U. Englert, L. Maron and J. Okuda, J. Am. Chem. Soc., 2018, 140, 3403-3411.
53 C. Ruspic and S. Harder, Inorg. Chem., 2007, 46, 1042610433.

54 C. N. de Bruin-Dickason, T. Sutcliffe, C. A. Lamsfus, G. B. Deacon, L. Maron and C. Jones, Chem. Commun., 2018, 54, 786-789.

55 A. S. S. Wilson, M. S. Hill, M. F. Mahon, C. Dinoi and L. Maron, Science, 2017, 358, 1168-1171.

56 A. S. S. Wilson, C. Dinoi, M. S. Hill, M. F. Mahon and L. Maron, Angew. Chem., Int. Ed., 2018, 57, 15500-15504.

57 M. Findlater, N. J. Hill and A. H. Cowley, Dalton Trans., 2008, 4419-4423.

58 M. Brookhart, M. L. H. Green and G. Parkin, Proc. Nat. Acad. Sci. U. S. A., 2007, 104, 6908.

59 A. W. Addison, T. N. Rao, J. Reedijk, J. Vanrijn and G. C. Verschoor, J. Chem. Soc., Dalton Trans., 1984, 13491356.

60 M. L. Cole, D. J. Evans, P. C. Junk and L. M. Louis, New J. Chem., 2002, 26, 1015-1024.

61 M. Arrowsmith, M. R. Crimmin, M. S. Hill, S. L. Lomas, M. S. Heng, P. B. Hitchcock and G. Kociok-Köhn, Dalton Trans., 2014, 43, 14249-14256.

62 S. Harder, Organometallics, 2002, 21, 3782-3787.

63 A. G. Avent, M. R. Crimmin, M. S. Hill and P. B. Hitchcock, Dalton Trans., 2005, 278-284. 